\title{
Assessment of Challenges and Opportunities of Composting Organic Solid Wastes: The Case of Robe Town, Oromia Regional State, Ethiopia
}

\author{
Aliyi Mama Gasu1, Uma Devi Pongiya ${ }^{2 *}$ and Fatuma Hamid Mohammed² \\ ${ }^{1}$ Department of Environmental Science, College of Natural and Computational Science, Maddawalabu University, Robe Bale, Ethiopia \\ ${ }^{2}$ Department of Chemistry, College of Natural and Computational Science, Maddawalabu University, Robe Bale, Ethiopia
}

\begin{abstract}
Composting is used in the management as a method to recover organic wastes. It provides the environmental and health benefits by reducing the survival and spread of pathogens. The growth of urban population and economic activities has resulted in corresponding growth of solid waste in Robe town. However, the traditional approach to organic solid waste management in the town focuses on the end of line solutions that are capital intensive, and therefore costly. The main purpose of the current study was to assess the challenges and opportunities of composting organic solid wastes. The research used descriptive method with survey strategy. To draw the sample, both probability and nonprobability sampling method were used and the total sample sizes of 384 from the three selected kebeles were selected proportionally to their respective household numbers. Both qualitative and quantitative tools such as questionnaires, interview, field observation and photography were used to collect the required data. The data quality was measured in terms of validity, reliability and practicability. The data were analyzed using, SPSS and Microsoft Excel. The finding of the study revealed that, there is no proper composting of organic solid wastes in the town. The challenges that hold back the implementation of composting organic solid waste includes lack of awareness, lack of adequate space for composting, lack of support from government, policy frame work, institutional problem (lack of department of urban agriculture) and budget constraint. However, the opportunities are availability of huge amount of organic wastes, farmers engaged in urban agriculture, suitable environment for composting, huge demand for organic fertilizer and an increase in price of chemical fertilizer.
\end{abstract}

Keywords: Challenges; Opportunities; Compost; Organic waste; Waste management

\section{Introduction}

The composting process entails managing and accelerating the biological and oxygen demanding process as a mixture of organic materials pass through a series of stages that are characterized by increases in temperature and bacterial types, leading to a stable organic material called compost [1]. A somewhat more low technology approach to waste reduction is composting. The waste in many developing nations would theoretically be ideal for reduction through composting, having a much higher composition of organic material than in industrialized countries, the average town's municipal waste stream is over 50 percent organic material [2]. Like in many developing countries, rapid population growth in relation with natural growth, high rural urban and urban-urban migration poses many environmental problems in general and solid waste (organic and inorganic) in particular for urban areas of Ethiopia. So, inadequate management of organic solid waste has resulted in accumulation of waste on open land, drainage, roads and living areas of many people [3]. The growth of urban populations and economic activities has resulted in corresponding growth of solid waste generation in Robe Town. Solid waste in Robe town is characterized by high organic content and also the municipality devotes substantial proportion of their budget to collect, transport and disposing of organic waste to open disposal sites. Uncollected and poorly managed organic solid wastes are a health and environmental hazard to the residents, especially to the urban poor who live near informal and often illegal waste dumps [4]. The municipal government is finding it difficult to dispose of those wastes. Existing dump site is filling up, and land for new ones is becoming increasingly difficult owing to scarcity of land with in municipal boundaries and the fact that surrounding rural communities are refusing permission to have dump sites located in their vicinity. Since the traditional approaches to organic solid waste management in Robe are capital intensive and costly there is a need for somewhat more low technology approach to organic waste reduction, composting which changes organic waste to valuable resource. The objective of the study is to assess the extent, challenges and opportunities of composting organic solid waste in Robe town.

\section{Methodology}

For the purpose of the current study, descriptive survey study method using both quantitative and qualitative research approach were employed. Because, the combination of the two research approach gives better interpretation as the information missed by one might be captured by the other and thus an enhanced and integrated result may emerge from the analysis. The quantitative data was employed by closed ended questions and qualitative data was employed in open-ended questions and observation [5]. A systematic sampling technique was used for selecting respondents from all the three kebeles in proportion to their respective households. From the total households in the town administration 374 respondents were selected from households and 10 from government officials and formal business operators. Therefore a total of 384 units were taken as the sample. The sampling techniques of this research were both probability and non probability sampling techniques [6]. After selecting the three kebeles, probability proportionate to their respective household number was distributed; to

*Corresponding author: Pongiya UD, Department of Chemistry, College of Natural and Computational Science, Maddawalabu University, Robe Bale, Ethiopia, Tel: +251924894687; E-mail: umadevipongiya@rediffmail.com

Received August 26, 2017; Accepted September 23, 2017; Published September 29, 2017

Citation: Gasu AM, Pongiya UD, Mohammed FH (2017) Assessment of Challenges and Opportunities of Composting Organic Solid Wastes: The Case of Robe Town, Oromia Regional State, Ethiopia. J Environ Anal Toxicol 7: 511. doi: 10.4172/21610525.1000511

Copyright: () 2017 Gasu AM, et al. This is an open-access article distributed under the terms of the Creative Commons Attribution License, which permits unrestricted use, distribution, and reproduction in any medium, provided the original author and source are credited. 
Citation: Gasu AM, Pongiya UD, Mohammed FH (2017) Assessment of Challenges and Opportunities of Composting Organic Solid Wastes: The Case of Robe Town, Oromia Regional State, Ethiopia. J Environ Anal Toxicol 7: 511. doi: 10.4172/2161-0525.1000511

Page 2 of 6

select 374 respondents through systematic sampling based on sampling frame of population of 13,156 households. In order to select 10 government officials purposive sampling was used to gather in depth qualitative data. Primary data collection the main data sources were 374 households that situated in the town and 10 government and formal business operators. Secondary data was collected from published and unpublished literatures; previous studies done by researchers, data from relevant bodies that have been working in related discipline in the town [7]. Data was collected through structured questionnaires, interviews and field observation from both qualitative and quantitative category. The collected data were safely organized, coded and input into Microsoft excel and SPSS as per its analytical need. The researcher was measured the data quality in terms of validity, reliability and practicability.

\section{Findings of the study}

The extent of composting practice in robe: According to the result obtained from the structured questioner filled by selected respondents, there is no proper composting activity of organic solid wastes in Robe town. But some of respondents were dumping organic wastes everywhere in the open spaces at $43.6 \%$ and $33 \%$ of respondents were using organic wastes as fire wood (specially animal dung) which is commonly known as "Fando" and "Falti" in afan oromo (local language) language and those who are engaged in grain production were dumping their organic wastes in their field to be decomposed after a long period of time and some of the respondents were also indicated as they used the waste for Animals feed and backyard composting [8-10]. The ways that the respondents were using organic wastes are summarized in the Figure 1.

The pilot composting practices: The composting practice in Robe town was simply the use of organic waste generated from the animal residue in some individual's backyard. That means at this time, it is implementing by few individuals at household level which attempt to convert the potential capacity of these organic solid wastes to other useful resource used as a soil conditioner. This is to recover the resource through composting instead of dumping through setting up of non mechanized aerobic composting technique (Figure 2).

The findings of the study shows that the most significant challenge in composting organic solid wastes is lack of awareness and the other challenges are presented in Figure 3. According to Figure 4, the least challenge for composting organic solid waste is lack of support from the local government which is $11.6 \%$, where as lack of adequate space for composting and lack of knowledge about the advantage of compost over the chemical fertilizer are also the challenges associated with composting in the town [11]. In addition to the above challenges that the community faced; the challenges that the municipality as the institution faced are listed below according to their rank (Table 1).

Opportunities for composting organic solid wastes: The finding of the study shows that, availability of huge amount of organic solid wastes are the greatest opportunity for the implementation of composting at $59.8 \%$ and the other opportunities are listed in the Figure 5.

As shown in the Figure 5, the least opportunity for composting organic solid wastes is suitable environment for composting at $7.9 \%$. The other opportunities include a farmers engaged in urban agriculture, huge demand for organic fertilizer and increase in price of chemical fertilizer were the major opportunities identified during the field survey [12]. Due to an increase in price of chemical fertilizer the majority of respondents spent 801-1600 Birr annually at 29.9\% (Figure 6).

According to Figure 6 only very few respondents expend less than 200 Birr annually at $4.7 \%$, and the rest were expend, 201-400, 401-800, 801-1600 and above 1600 birr every year.

This indicates that urban farmers were exposed to external cost to increase the soil fertility of their farm land due to lack of knowledge to compost the organic wastes generated from their home and agricultural land.

\section{Interpretation and Discussion}

\section{Current organic solid waste handling practice in robe town}

In the town there is no standard laid down for organic solid wastes disposal and there is no central composting plant. Instead of composting this economically and environmentally friendly resource it is dumped in the open spaces and along the main roads.

According to the municipal manager, organic wastes generated from the animal dung and food residues (commercial center) accounts $80 \%$ of the total municipal wastes generated in the town. This is due to that the existence of agricultural activity in the town which contributes to the organic waste generation. As such amount of organic solid waste is dumped in open spaces and along the main road from Robe town to Hora Boka, Robe town to Waltai, Robe town to Hawsho, Robe town to Bassasso and Robe town to Goba High way it is causing bad smell after a period of time through decomposition and polluting the surrounding environment.

Hence, in the town this practice is adversely affecting the environment and has its own socio economic consequence that contribute to less aesthetic value of the town and posing treat to the public health due to the dumping of organic solid wastes in the

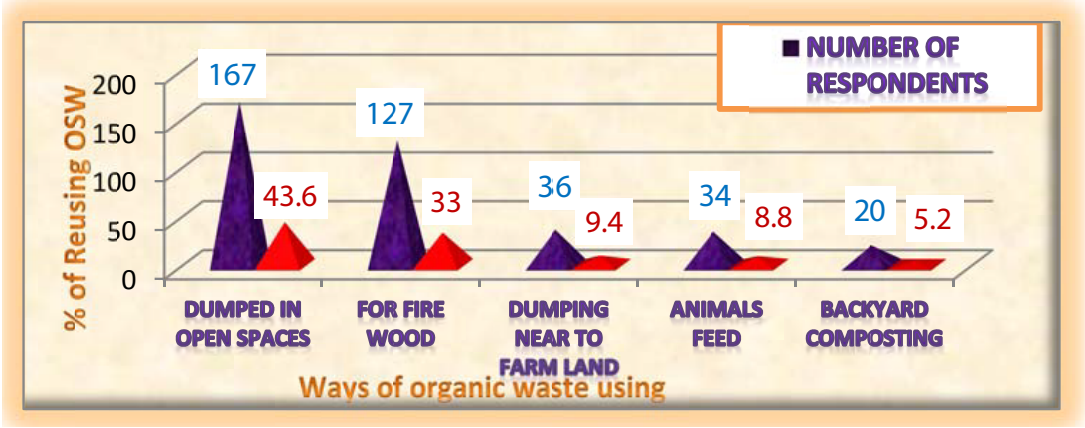

Figure 1: Ways of reusing organic solid wastes (Field survey, 2015). 
Citation: Gasu AM, Pongiya UD, Mohammed FH (2017) Assessment of Challenges and Opportunities of Composting Organic Solid Wastes: The Case of Robe Town, Oromia Regional State, Ethiopia. J Environ Anal Toxicol 7: 511. doi: 10.4172/2161-0525.1000511

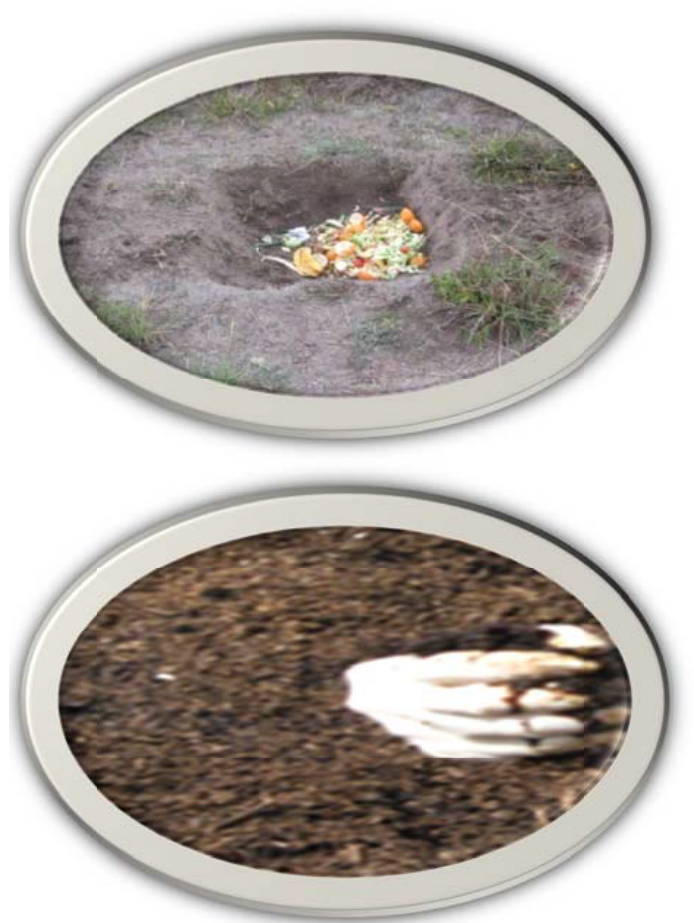

Figure 2: Challenges associated with composting organic solid wastes. Pilot composting practices in Baha Biftu Kebele (Field survey, 2015).

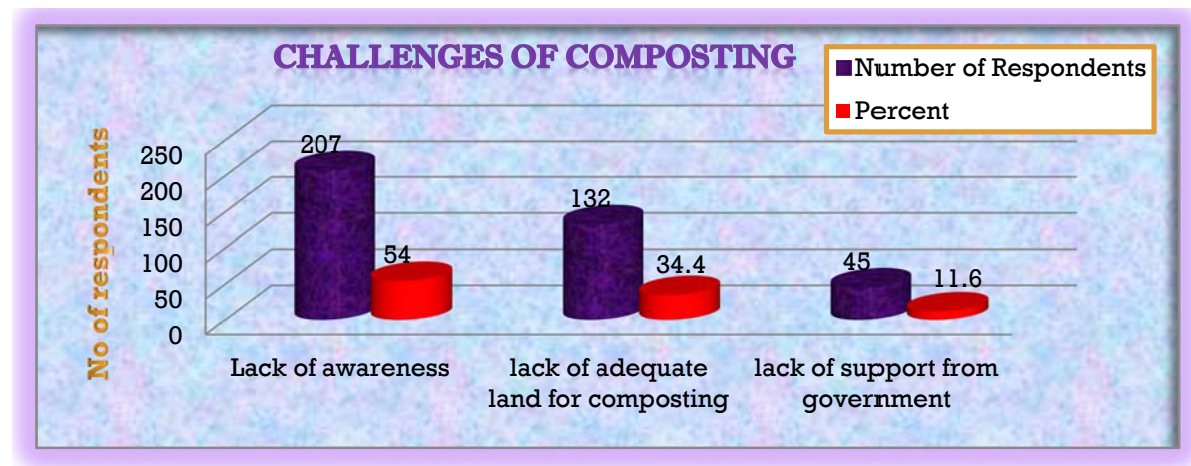

Figure 3: Challenges of compost (Field source, 2015).

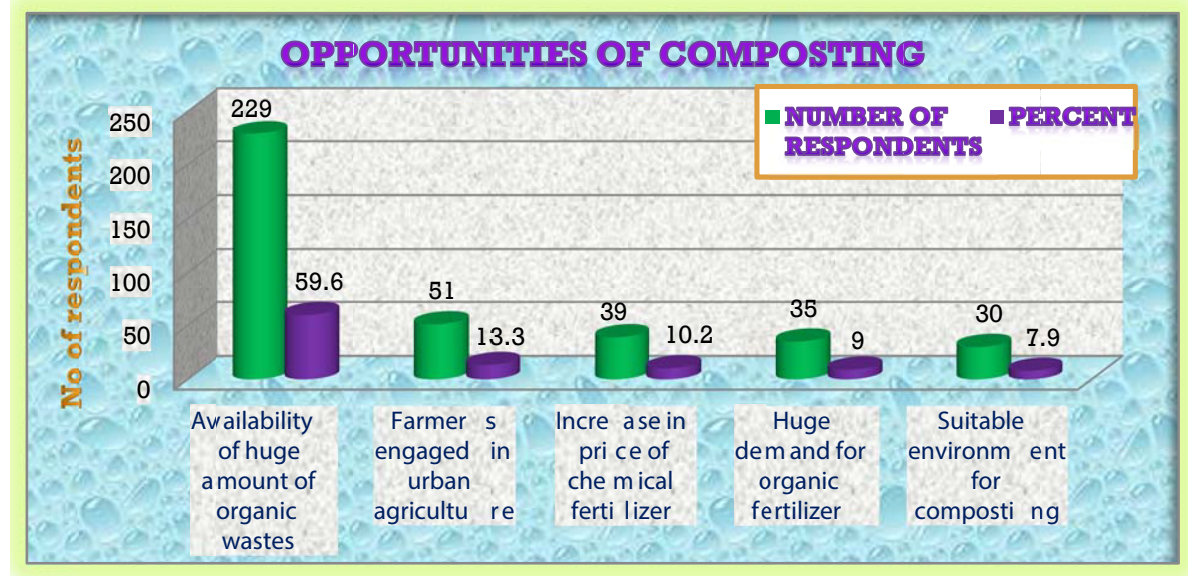

Figure 4: Opportunities for composting (Field survey, 2015). 
Citation: Gasu AM, Pongiya UD, Mohammed FH (2017) Assessment of Challenges and Opportunities of Composting Organic Solid Wastes: The Case of Robe Town, Oromia Regional State, Ethiopia. J Environ Anal Toxicol 7: 511. doi: 10.4172/2161-0525.1000511

Page 4 of 6

surrounding environment. Similar to this, World Bank indicated solid waste in less developed country is dumped improperly in open spaces [13]. The following plate shows organic solid wastes dumped along the main road from Robe town to waltai and Robe town to Goba town (Figure 7).

\section{Challenges of composting organic solid wastes}

The interview made with the municipal manager of Robe town stated several issues related to composting organic solid wastes and their current management activities. According to interview, the major challenges associated with composting organic solid wastes includes

\begin{tabular}{|l|c|c|c|c|}
\hline Challenges & 1 $^{\text {st }}$ Rank & $2^{\text {nd }}$ Rank & $\mathbf{3}^{\text {rd }}$ Rank & $\mathbf{4}^{\text {th }}$ Rank \\
\hline Policy frame work & $\mathrm{X}$ & & & \\
\hline $\begin{array}{l}\text { Institutional problem (lack of } \\
\text { department of urban agriculture) }\end{array}$ & & $\mathrm{X}$ & & \\
\hline Financial problem/Budget constraint & & & $\mathrm{X}$ & \\
\hline Lack of awareness & & & & $\mathrm{X}$ \\
\hline
\end{tabular}

Table 1: Challenges of composting faced by municipality (Field survey, 2015). financial problem, policy frame work, institutional frame work (lack of department of urban agriculture), lack of awareness, and poor waste management practice [14].

Policy framework about composting urban organic solid wastes: According to Plahl, Political will must exist to formulate and implement policy promoting composting in line to enhance participation in terms of household waste separation [15]. Hence, not in my backyard can present a problem both in developed and developing countries when selecting waste management sites. Again, plahl stated as legislation and its effective enforcement is a key issue to sustainability for which the framework requires to be established [15]. Municipal authority should have management structure and framework of legislation for effective composting of organic solid wastes. But, in Robe municipality there is no any strict policy framework that initiates composting of organic solid wastes as way of organic solid waste management system. That is why this valuable resource is dumped in open spaces found in near distance from the residential areas and polluting the neighboring environment.

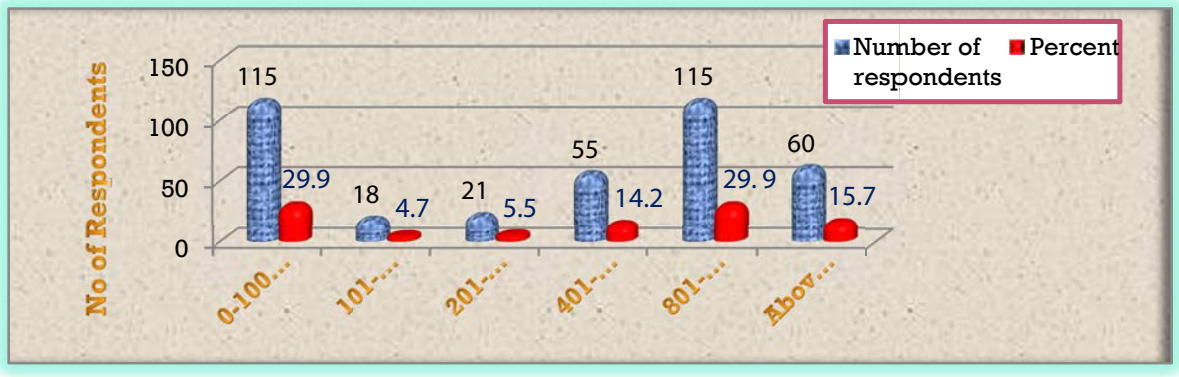

Figure 5: Annual expenditure of chemical fertilizer (Field survey, 2015).

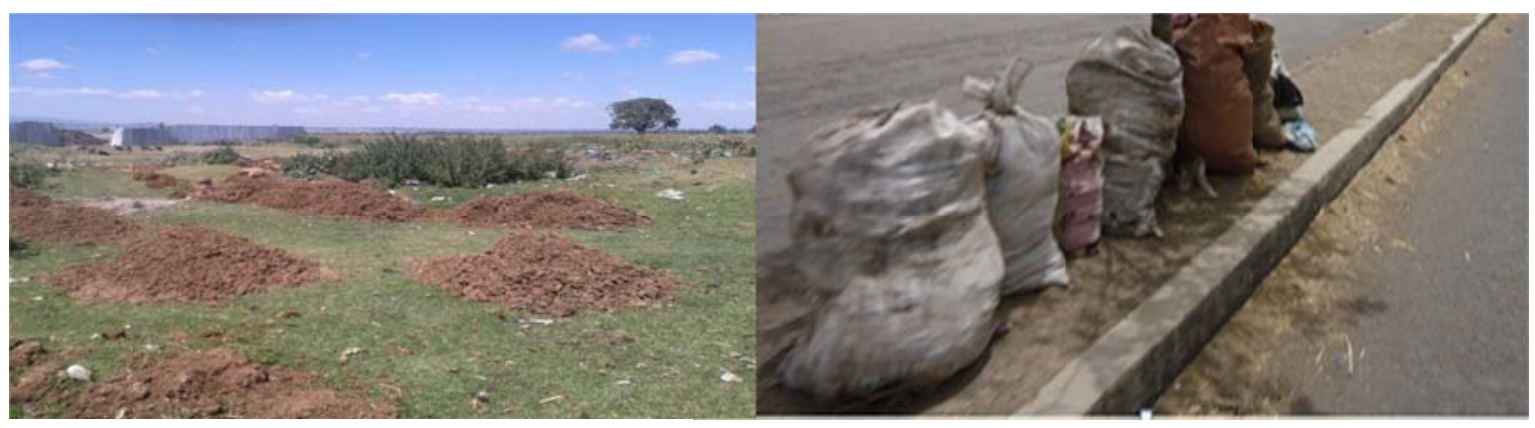

Figure 6: Organic waste dumped on the field and road side (Field survey, 2015).
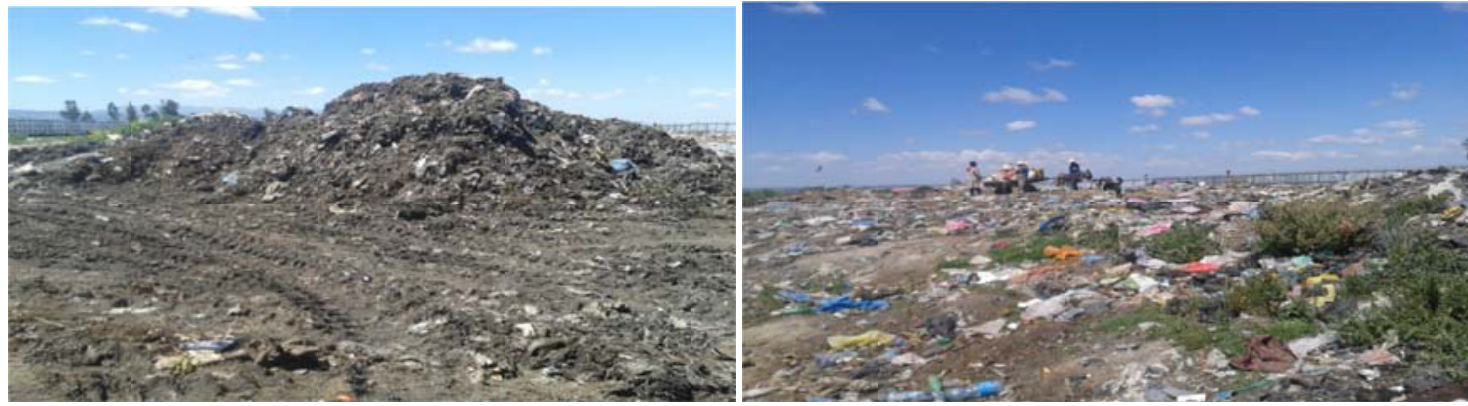

Figure 7: Existing dump site (Field Survey, 2015). 
Citation: Gasu AM, Pongiya UD, Mohammed FH (2017) Assessment of Challenges and Opportunities of Composting Organic Solid Wastes: The Case of Robe Town, Oromia Regional State, Ethiopia. J Environ Anal Toxicol 7: 511. doi: 10.4172/2161-0525.1000511

Page 5 of 6

Lack of department of urban agriculture (institutional problem): According to Green and Kramer in the early $20^{\text {th }}$ century, urban societies began to grow and to have a noticeable department on the management of waste because of the increasing amount of urban waste and wastewater produced [16]. However the finding of this study revealed that, as there is no urban agriculture department in the town to encourage composting urban agricultural activities to increase the fertility and water holding capacity of the soil. Even if there is no urban agriculture department, urban farmers engaged in grain production activities using organic waste dumped in their field and backyard decomposed after a period of time as a soil conditioner. Hence, the establishment of the department of urban agriculture was depending on the policy framework.

Budget or financial constraint: After taking into consideration the expense of compost (US $\$ 5.80$ per ton of compost, or US $\$ 3.08$ per ton of waste processed) and recyclable sales, the municipality is required to subsidize the operation at a cost of US $\$ 10.76 /$ ton of waste processed. However, financial issues are the main problems for most of the developing countries including Ethiopia and also in the study area World Bank [12]. For the establishment of organic solid waste composting plant it needs start up budget for site clearing, transportation of organic wastes from source to composting plant and payment for daily laborer. Hence, in Robe town, low priority is given for composting organic wastes as a result very limited budget is allocated to manage their organic solid wastes.

Lack of awareness about advantage of compost in case of the environment: As Drechsel and Kunze, reported most people are awared that using composts is an effective way to increase healthy plant production, helps to save money, reduce the use of chemical fertilizers, and conserve natural resources [16]. However, in Robe town there is no awareness creation about the advantages of compost to the environment by municipality to initiate the use of composting of organic wastes by urban farmers in and around the town.

Lack of knowledge about compost preparation: According to the finding of the study most of the urban farmers were not know the right way of compost preparation. Due to this, most of the respondents engaged in agriculture uses chemical fertilizer to improve soil fertility and made an expenditure on average more than 1200 Birr annually.

Lack of knowledge about the advantage of compost over the chemical fertilizer: Sapuay stated as compost provides a stable organic matter that improves the physical, chemical, and biological properties of soils, thereby enhancing soil quality and crop production; When correctly applied, compost has valuable effects on soil properties, thus creating suitable conditions for root development and consequently promoting higher yield and higher quality of crops [17]. Compost provides a stable organic matter that improves the physical, chemical, and biological properties of soils, thereby enhancing soil quality and crop production. Meanwhile, most of the respondents in the study area had no detail knowledge about the compost.

\section{Opportunities for composting organic solid wastes}

Availability of huge amount of organic wastes suitable for composting: According to interview made with the head of the department of sanitation and beautification the organic waste generated accounts $80 \%$ of the total municipal solid waste of the town. But due to several challenges this huge amount of resource is disposed in open spaces in the town. After some times the organic solid waste is decomposed and used by near urban farmers as compost. Plate 3.1, shows that organic solid wastes decomposed and used by urban farmer engaged in vegetable production in the backyard.
Existing dump site is filled up: In Robe town, due to the filling-up of the current open waste disposal site, sometimes waste is dumped in the open spaces near to the residential area and the main road (Figure 7).

Regarding the existing situation of organic solid wastes management activity, the municipal track dumps the organic waste near the main road and this create rumor in the town. Previously the organic wastes are dumped in open spaces inside and preferring the town but nowadays the situation become very hard due to the assimilative capacity of the environment is decreasing and decomposition of organic wastes and polluting the surrounding environment as well as the residents do not allow to dump the waste near their home and this situation become an opportunity that forces the municipality to establish central composting to manage the organic wastes in environmentally sound method.

Huge demand for compost by urban farmers engaged in grain production: According to Petts, Public health officials may discourage household composting because of perceived health risks, however, local governments can overcome this concern through public awareness programs, providing subsidies for basic composting units, and promoting education on compost processes [17].

However, most of the urban farmers engaged in grain production have been using chemical fertilizer to improve the soil fertility of their farm land. But currently due to an increase in price of chemical fertilizer some farmers starts to collect the organic solid wastes in their field to be decomposed and used as a soil conditioner to improve the productivity of their farm land. So an increase in price of chemical also increases the demand for organic fertilizers (compost) which is less cost compared to the chemical fertilizer.

An increase in price of chemical fertilizer: Most of the respondents participated in the study were urban farmers; they are using chemical fertilizer to improve the soil fertility of their agricultural land. Previously because of the subsidy made by the federal government the price of the chemical fertilizer were too low. But at the moment the subsidies made by the government were banned and the price of chemical too high and forces urban farmers to make organic fertilizer from locally available organic solid wastes.

\section{Conclusion}

Regarding the extent on composting organic solid wastes, there is no proper composting activity in the town. Only few urban farmers engaged in Grain production and backyard vegetable producers were dumping their organic wastes in their field and backyard to be decomposed after a long period of time to use it as compost. But some of respondents were dumping their organic wastes in the area near their farm land (especially animal dung and food residue) to be decomposed which in turn support urban agriculture and some of them were drying up and uses as a fire wood.

Linking compost with urban agriculture seems to have most potential, because of low transporting costs and direct benefits to urban farmers. This may cause the closure of nutrient cycles, a reduction in transporting costs and the use of chemical fertilizer, available space and labor made more productive and create healthier urban environment. Urban agriculture and composting seem to be capable activities which can contribute to solve the complex urban problems. There are various options for the use of compost, such as agriculture in pre-urban and urban areas, green spaces in the town, parks and recreational areas.

In the town there are no standards laid down for organic solid wastes disposal and also there is central composting plant. So instead of composting this economically and environmentally sound resource is dumped on open spaces and along the main roads. 
Citation: Gasu AM, Pongiya UD, Mohammed FH (2017) Assessment of Challenges and Opportunities of Composting Organic Solid Wastes: The Case of Robe Town, Oromia Regional State, Ethiopia. J Environ Anal Toxicol 7: 511. doi: 10.4172/2161-0525.1000511

Page 6 of 6

The major challenges associated with composting organic solid wastes includes financial problem, policy frame work, institutional frame work (lack of department of urban agriculture), lack of awareness about compost preparation and its advantage over chemical fertilizer, and poor waste management practice in case of Robe town.

Even though there are various challenges, still the opportunities overweight the challenges because in Robe town, due to the main agricultural activities (pastoral and grain production) in the town every day more than $160 \mathrm{~m}^{3}$ of compostable waste is generated which accounts $80 \%$ of the total municipal solid waste of the town. And the other opportunities include suitable environment for composting, farmers engaged in urban agriculture, huge demand for organic fertilizer and increase in price of chemical fertilizer were the major opportunities identified during the study.

\section{Recommendations}

In light of the above findings and conclusions, the following recommendations are forwarded.

\section{Provide training for urban farmers on home composting}

Awareness and understanding of basic principle of composting are essential to promote home composting at household level. Hence, the municipality or the department of urban agriculture should plan to provide training for all the urban farmers on the proper composting mechanism for the organic solid wastes generated from their home and their farm land.

\section{Establishing composting plant by municipality}

Municipality and other government bodies need to enhance composting activity by organizing unemployed youth in the town to participate in composting activities. Given the fact that, high composition of organic solid waste in the town, the municipality needs to establish central composting plant. Moreover, for meaning full change and environmental sustainability as well as for the interaction between rural and urban centers establishment of composting plant is very crucial.

\section{Clear policy framework}

Clear policy framework and regulations on composting of organic solid wastes should be formulated, because many problems associated with composting organic solid wastes are related to lack of adequate attention from responsible government bodies. Policy issues that encourage private sector involvement in collecting and composting of organic solid waste should be addressed. Because most of the policies for agriculture do not recognize the important role that urban agriculture could play to the economy and environment. As a result of this, there is often a feeling of insecurity among urban farmers; thereby limiting their commitment to investment in urban farming which directly affects the implementation of composting of organic solid wastes.

\section{Promoting urban agriculture}

Since the compost is an important input for agriculture, expanding and promoting urban agriculture is important not only to stimulate the production of compost but also to promote increased use among urban and pre-urban farmers.

\section{Recommendation for further study}

Assessing the challenges and opportunities for composting organic solid waste in the town by applying different data collection tool with large sample size may result in identifying the challenges and opportunities in depth which will in turn contribute value to prepare comprehensive plan for the development of the town.

\section{Acknowledgements}

The authors would like to express their sincere thanks to Maddawalabu University which helped us throughout our work, informants who work under the various offices of Robe town administration. Our special thanks also extend to three kebeles respondents of Robe town) for giving us relevant information and for their kind cooperation.

\section{References}

1. Haight F, Taylor H (2000) Waste audit user's manual: a comprehensive guide to the waste audit process. Winnipeg, MB: Manitoba Statutory Publishing.

2. Chefetz B, Hatcher PG, Hadar Y, Chen Y (2006) Municipal Organic waste characterization and management strategies for the Lower Rio Valley, Texas. Waste Manage 28: 776-794.

3. Ministry of Health (2009) Ethiopian Health Sector Development program, Addis Ababa, Ethiopia.

4. Robe town Municipality (2014) Municipality annual report unpublished data.

5. Achankeng E (2003) Globalization, Urbanization and Municipal Solid Waste Management in Africa. African Studies Association and the Pacific. 2003 Conference Proceedings-African on a Global Stage.

6. Chakrabarti S, Sarkhel P (2003) Economics of solid waste management A survey of existing literature. Economic Research Unit, Indian Statistical Institute, Kolkata.

7. Cherles L, Robert A, Mery K (2012) Waste management and resource recovery. Lewis Publisher, United States of America.

8. Chokean A, Cumpakorn B (2007) Organic waste compost methods in Bangkok Households School of Architecture and Design. King Mongkut's University of Technology Thonburi, Thailand.

9. Hansen TL, Schmidt JE, Angelidaki I, Marca E, Mosbæk H, et al. (2004) Method for determination of methane potentials of solid organic waste. Waste Manag 24: 393-400.

10. Hoornweg D, Thomas L, Otten L (1999) Composting and its applicability in developing countries. World Bank Working Paper Series.

11. World Bank (2005) Urban Development Working Papers East Asia Infrastructure Development World Bank, Waste Management in China: Issues and Recommendations. Working Paper, China.

12. Pace MG, Miller BE, Farrell Poe KL (2005) The composting process. Utah State University Extension.

13. Plahl F, Rogalski W, Gilnreiner G, Erhart E (2002) Vienna's Biowaste Compost Quality.

14. Green JH, Kramer A (2007) Food processing waste management. The AVI Publishing Company Inc. Westport, Connecticut. Printed in the United States of America, pp: 1-14.

15. Drechsel P, Kunze D (2001) Waste composting for urban and peri-urban agriculture: Closing the rural-urban nutrient cycle in sub-Saharan Africa. CABI

16. Sapuay GP (2005) Ecological Solid Waste Management Act of 2000 (RA 9003): A major step to better solid waste management in the Philippines. In International Conference on Integrated Solid Waste Management in Southeast Asian Cities, Siem Reap, pp: 51-59.

17. Petts A (1995) Waste Management Strategy Development: J Environ Plan Manag 20: 12-17. 